\title{
Synchronization of cyclic and acyclic embryo recipient mares with donor mares
}

\author{
Ivan V. Oliveira Neto ${ }^{\mathrm{a}}$, Igor F. Canisso ${ }^{\mathrm{b}}$, Lorenzo G. Segabinazzi ${ }^{\mathrm{a}}$, \\ Camila P.F. Dell'Aqua ${ }^{a}$, Marco A. Alvarenga ${ }^{a}$, Frederico O. Papa ${ }^{a}$, \\ Jose A. Dell'Aqua Jr. ${ }^{\text {a,* }}$ \\ a Department of Animal Reproduction and Veterinary Radiology, School of Veterinary Medicine and Animal Science, São Paulo State University \\ (UNESP), Botucatu, Brazil \\ ${ }^{\mathrm{b}}$ Department of Veterinary Clinical Medicine, College of Veterinary Medicine, University of Illinois Urbana-Champaign, Urbana IL 61802, USA
}

\section{A R T I C L E I N F O}

\section{Keywords:}

Embryo transfer

Uterine edema

Hormone therapy

Estrogen

Progestin

\begin{abstract}
A B S T R A C T
This study compared hormone treatments given to mares during anestrus, spring transition, and different stages of the estrous cycle, by assessing uterine features and pregnancy rates after embryo transfer $(E T)$. Embryo recipient mares $(n=160)$ were equally arranged as follows: $\mathrm{G1}$ spontaneous ovulation (control), G2-anestrus, G3-spring transition, G4-early estrus, G5-estrus, G6-diestrus, G7-early diestrus treated with a dose of dinoprost, and G8-early diestrus treated with two doses of dinoprost. At treatment initiation (Day-4), G2-7 were given dinoprost and estradiol$17 \beta$, thereafter, estradiol-17 $\beta$ was repeated on Days-3,-2, and -1. On Day0, mares received longacting altrenogest. Then, each mare had one ET performed from Day +3 to Day +8 after altrenogest. Immediately before the ET, mares received a boost of altrenogest and had uterine features assessed. Pregnant mares on each of the checks (by 7, 30, 60, and 120d after ET) were maintained on weekly injections of LA-P4 until 120d. G8 received similar management, but dinoprost was repeated on Day-3. G1-G6 and G8 displayed uterine edema and satisfactory pregnancy rates $\geq 65 \%$. Repeating dinoprost to G8 likely ensured proper luteolysis and response to estrogen as determined by higher uterine edema scores and pregnancy rates than G7 ( $<<.05)$. Our results were consistent with previous studies and other successful commercial ET programs (except G7), thus, demonstrating the usefulness of the hormone treatments described herein to synchronize embryo recipient mares with donor mares. Thus, we foresee that other groups may use the strategies described herein for the management of embryo recipient mares.
\end{abstract}

\section{Introduction}

Embryo transfer is an assisted reproductive technique used to maximize the number of offspring from mares with a desired phenotype, or as a tool to circumvent health or reproductive dysfunction (e.g., chronic orthopedic issues, recurrent embryonic loss, or severely fibrotic endometrium), or to obtain foals from fillies or mares with an active athletic career (Squires et al., 1999; Panzani et al., 2007; Campbell, 2014; McCue and Squires, 2015). The success of an embryo transfer program is affected by multiple factors, such as the management and fertility of dams and sires, experience of the professional(s) collecting and transferring embryos, and quality and management of recipient mares (Squires et al., 1999; McKinnon et al., 1988; McCue and Squires, 2015).

\footnotetext{
* Corresponding author.

E-mail address: dellaquajunior@uol.com.br (J.A. Dell'Aqua).
} 
The viability of a commercial embryo transfer program relies heavily on maintaining and managing surrogate mares, as caring for these animals represents the most costly component of a program. Successful programs typically have high utilization rates of recipient mares with satisfactory pregnancy rates after the embryo transfer (e.g., $\geq 70 \%$ ) (McCue and Squires, 2015). Synchronization of embryo recipients with donor mares is one of the limiting factors for high usage of recipient mares with good pregnancy rates (McCue and Squires, 2015). Though, while a large number of equine embryos are produced and transferred worldwide, the literature is particularly scarce concerning the onset of synchronization protocols of an embryo recipient mare and a donor mare during different stages of the estrous cycle (i.e., early vs. late estrus or diestrus).

Reported synchronization protocols may involve the use of prostaglandin F2 $\alpha$ (i.e., dinoprost tromethamine) or its analogs (e.g., sodium cloprostenol), steroid hormones (progestins and estrogens), and ovulation induction agents such as human chorionic gonadotropin and GnRH agonists (e.g., deslorelin acetate, histrelin) (Carnevale et al., 2000; McCue et al., 2002; Rocha Filho et al., 2004; Carnevale et al., 2005; Caiado et al., 2007; Fleury et al., 2007; Greco et al., 2008; Greco et al., 2012; Kaercher et al., 2013; McCue and Squires, 2015; Greco et al., 2016; Pinto et al., 2017). Prostaglandin F2 $\alpha$ alone is commonly used in cyclic mares to bring them back into estrus when necessary (Cuervo-Arango et al., 2017). Whereas, a combination of estrogen (e.g., estradiol 17 $\beta$, estradiol benzoate, or estradiol cypionate) and progestin (e.g., altrenogest, or progesterone) is typically used in acyclic and transitional recipient mares or when there is a shortage of recipient mares, demanding a tight-synchrony between one embryo donor and one or two of its recipients (Rocha Filho et al., 2004; Greco et al., 2012; McCue and Squires, 2015; Silva et al., 2017; Pinto et al., 2017).

In large-scale commercial programs, embryo recipient mares are kept in large groups and frequently checked by transrectal palpation and ultrasonography to determine the optimal ovulation synchrony with embryo donor mares (Squires et al., 1999; McCue and Squires, 2015). Checking recipient mares is a costly and time-consuming activity that requires well-trained personnel to carry out large number of scans and proper determination of ovulation synchrony with embryo donor mares. Therefore, hormone treatments allowing synchronization of embryo recipients with donor mares could prove useful to maximize the use of recipient mares and to minimize the number of ultrasonography examinations.

The overall objective of the present study was to optimize the synchronization of embryo recipient mares with donor mares. Specifically, we compared outcomes of hormone treatments, given to mares during anestrus, spring transition, and different stages of the estrous cycle, by assessing uterine features (edema, tone, and echotexture) and pregnancy rates of cooled-transported embryos.

\section{Materials and methods}

The present study was revised and approved by the Ethics Committee of the São Paulo State University (UNESP), Botucatu, São Paulo, Brazil under the protocol \# 130/2014-CEUA. This experiment was carried out during the breeding season of the Southern Hemisphere (from August 2016 to January 2017).

\subsection{Embryo recipient mares and management}

Light breed type embryo recipient mares $(n=160)$ aging from 5 to 15 years old $(9.5 \pm 3.6)$ were enrolled in the present study. The animals were kept in a commercial embryo recipient herd in Botucatu, São Paulo Brazil. The mares were kept on pasture of Tifton 85, with free choice water and trace minerals. Mares were regularly dewormed with ivermectin at 3-mo intervals and yearly vaccinated (including a 28-day boost) with a 5-way vaccine (Tri-Equi, Hetape-Calier ${ }^{\circledR}$ Juataba, Minas Gerais, Brazil). The recipients were brought to the farm, 6-8 weeks before enrolment in the embryo transfer program. All recipients remained in apparently good health and had good body condition scores during the study.

Embryo recipient mares $(n=160)$ were equally arranged into eight groups as follows: G1 spontaneous ovulation (control group); G2 anestrus, i.e., mares showing ovarian follicles $<15 \mathrm{~mm}$ in diameter and no detectable corpus luteum in 3 wks; G3 spring transition, i.e., mares presenting 25-30 mm follicles with no corpus luteum in 3 wks; G4 early estrus (follicles < $35 \mathrm{~mm}$ ); G5 estrus (follicles $\geq 35 \mathrm{~mm}$ ); G6 diestrus (ovulation $\geq 5$ days); G7 early diestrus (ovulation $<5$ days) treated with a single dose of prostaglandin; and G8 early diestrus (ovulation < 5 days) treated with two doses of prostaglandin one day apart (Fig. 1). All mares assigned to G1 and G4-8 had at least one ovulation confirmed before enrollment in the present study.

At treatment initiation (Day -4), animals in groups 2-7 were given dinoprost tromethamine (Lutalyse ${ }^{\oplus}, 10 \mathrm{mg}$, IM, Zoetis, São Paulo, Brazil) and estradiol 17ß (17 ßeta ${ }^{\oplus} 10 \mathrm{mg}$, IM, Botupharma, Botucatu, São Paulo, Brazil). Thereafter, estradiol 17 $\beta$ administration was repeated on Days $-3(10 \mathrm{mg}),-2(20 \mathrm{mg})$ and $-1(10 \mathrm{mg})$ (Fig. 1). On Day 0, all mares received a single dose of longacting altrenogest (Altrengest ${ }^{\circ}, 300 \mathrm{mg}$, IM, Botupharma). After that, each mare had one cooled-transported ( $<6 \mathrm{~h}$ ) day-8 embryo transferred from Day +3 to Day +8 (i.e., asynchrony of five to zero days after the donor mare's ovulation) after the altrenogest injection. On the day of the transfer, each mare received a boost of long-acting altrenogest (300 mg, IM). Mares in G8 received similar hormonal treatments with the exception that a second dose of dinoprost (10 mg) was given on Day - 3 (Fig. 1).

From Day -4 to Day -1 , all mares had uterine edema scored (0-3 scale) via transrectal ultrasonography B-mode ultrasound coupled with a $5 \mathrm{MHz}$ transducer (WellD, Pingshan, Shenzhen, China) (Fig. 2). No visible uterine edema was deemed as score 0 (Fig. 2A), and pronounced uterine edema at the uterine bifurcation was deemed as score 3 (Fig. 2D).

Mares assigned to the control group were monitored via transrectal palpation and ultrasonography every other day until a preovulatory follicle was detected and then daily until ovulation. The four days preceding the ovulation of mares in the control group (G1) were used retrospectively for comparisons of uterine edema with hormonally treated mares (G2-G8). The day of the embryo donor's mare ovulation or the immediate day after coincided with Day -4 for all embryo recipient mares. 


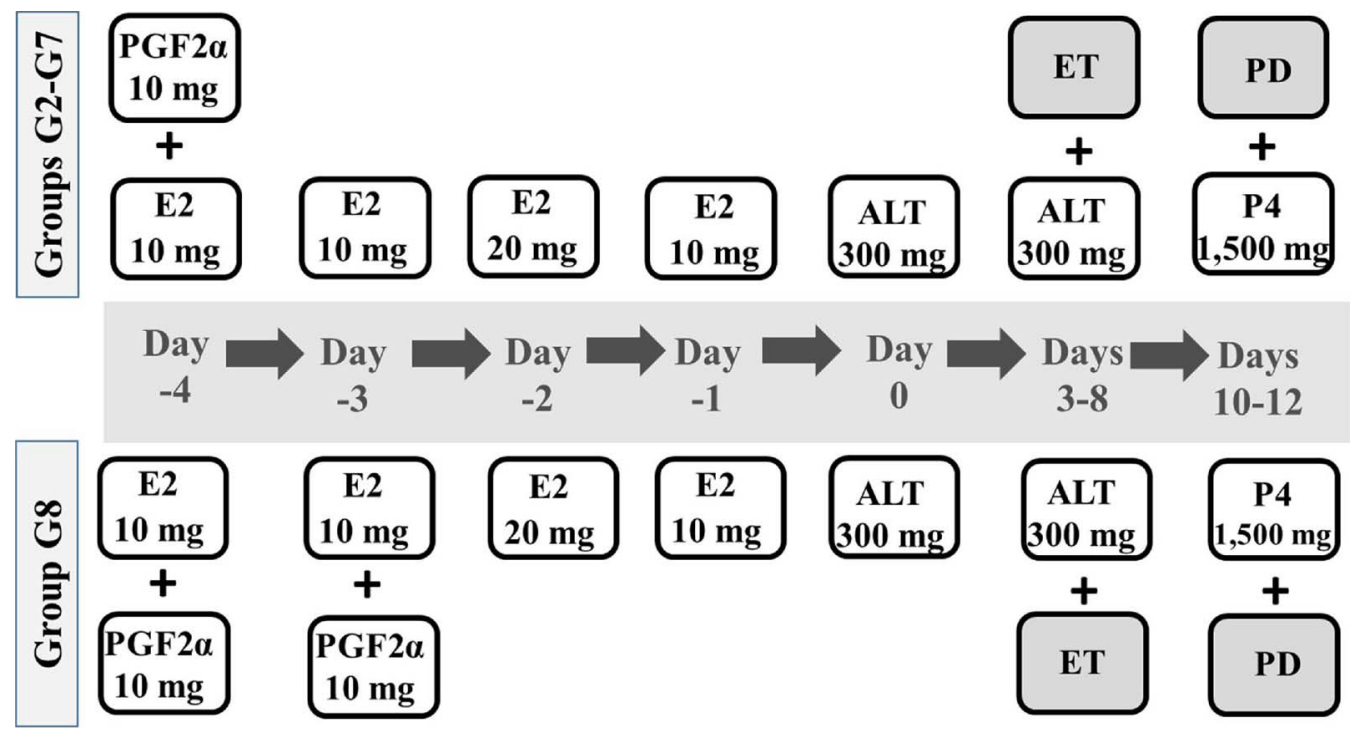

Fig. 1. Hormone treatments administered to mares assigned to the following groups:G2 anestrus, G3 spring transition, G4 early estrus (follicles < 35 mm), G5 estrus (follicles $\geq 35 \mathrm{~mm}$ ), G6 diestrus (ovulation $\geq 5$ days); G7 early diestrus (ovulation $<5$ days), G8 early diestrus (ovulation $<5$ days). Prostaglandin F2 $\alpha$ dinoprost tromethamine (Lutalyse ${ }^{\star}, 10 \mathrm{mg}$, IM); E2 estradiol 17ß (17 ßeta ${ }^{\star}, 10 \mathrm{mg}$, IM); ALT long-acting injectable altrenogest (Altrengest ${ }^{\star}, 300 \mathrm{mg} / \mathrm{mL}$, IM); P4 long-acting injectable progesterone (P4-300 $\mathrm{IM})$; ET embryo transfer. PD pregnancy diagnosis via ultrasound. Of interest, each recipient had hormone treatments initiated at the day of or the day after ovulation of an embryo donor.

\subsection{Breeding management of donor mares and embryo transfer procedures}

Ninety-two light breed with ages varying between 7 and 23 years-old (Quarter Horse, Warmblood, and Mangalarga Marchador) mares served as embryo donors. The mares were kept in private farms in the state of São Paulo, Brazil. Embryo donor mares were evaluated via transrectal palpation and ultrasonography, every other day until a pre-ovulatory follicle was detected. Once the preovulatory follicle reached $\geq 35 \mathrm{~mm}$ of diameter in the presence of good endometrial edema (2-3, Fig. 2C-D), ovulation was induced with a GnRH agonist ( $250 \mu \mathrm{g}$ of histrelin acetate, Strelin ${ }^{\star}$, Botupharma). Donor mares were artificially inseminated, with $0.5-1$ billion of progressively motile sperm, $24 \mathrm{~h}$ after the injection of the $\mathrm{GnRH}$ agonist. Mares were examined the next day to confirm ovulation and to check for the presence of intra-uterine fluid accumulation. Mares that did not ovulate were re-bred in similar manner. Intrauterine fluid accumulation was treated with oxytocin (20 units, q12 h, IM) and uterine lavage with $2 \mathrm{~L}$ of Lactated Ringer's Solution. Eight days after ovulation, standard transcervical embryo flushing was carried out with Lactated Ringer's solution (Alvarenga et al., 1993). The recovered uterine fluid was drained into filters; embryos were searched, located, separated, and classified and graded according to an illustrated guide published by The Equine Reproduction Laboratory, Colorado State University, Fort Collins, USA.

Only grade one embryos with normal developmental stage were used in the study. Following collection, the embryos were packed in $5 \mathrm{~mL}$ containing embryo medium (Botuembryo ${ }^{\circ}$, Botupharma) and shipped at $15^{\circ} \mathrm{C}$ in a commercial container (Botuflex , Botupharma) for $<6 \mathrm{~h}$ in standard fashion to the embryo recipient farm. After arrival on the farm, each embryo was examined under a stereomicroscope before being loaded on a standard AI pipette (large embryos visible with naked eyes) or Cassou gun (smaller embryos not visible with naked eyes) in preparation for the transfer.

Immediately before embryo transfer, each recipient mare was examined via transrectal palpation and ultrasonography. Parameters assessed included uterine tone ( $0-3$ scale) and echotexture on standard B-mode ultrasound coupled with a $5 \mathrm{MHz}$ transducer (WellD, Pingshan, Shenzhen, China); where a score 0 (minimum) was characterized by a heterogeneous uterine echotexture with distinct anechoic lines, and the score 3 (maximum) was characterized by a homogeneous uterine echotexture with no visible anechoic lines in the endometrial folds (Fig. 3D). Thereafter, all embryos were transcervically transferred into the uterine body, using a standard method, by a single well-experienced veterinarian.

Pregnancy diagnosis was carried out by 7 days (5-7 days after embryo transfer, i.e., 10-12 days after first altrenogest injection), 30, 60, and 120 days after embryo transfer. Mares confirmed to be pregnant at these time points were maintained on weekly injections of long-acting progesterone (1500 mg, IM, P4-300 ${ }^{\circ}$ Botupharma) until 120 days of gestation.

\subsection{Data analyses}

Statistical analyses were carried out with a commercial software (SAS 9.1.3, SAS Institute, Cary North Carolina, USA). Uterine features (edema, tone, and echotexture) were analyzed with the Kruskal-Wallis' test. Pregnancy rates were compared among groups by multivariate regression analysis. Uterine edema, tone, and echotexture scores are depicted as median and interquartile ranges (IR). Pregnancy rates are presented as percentiles (number of pregnancies/number of embryos transferred). Statistical significance was set 


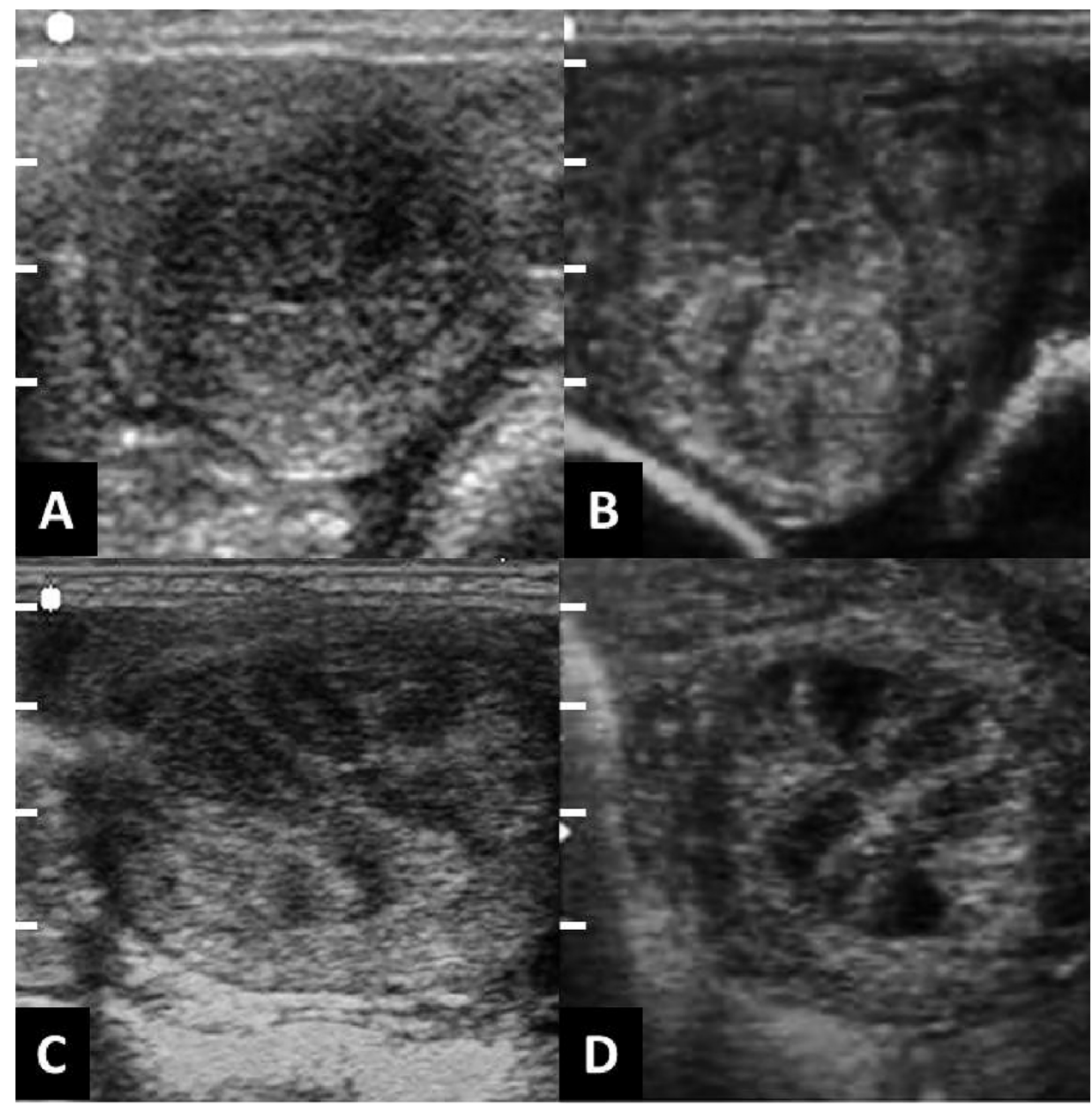

Fig. 2. Representative images of the grading system used for scoring uterine edema of all mares. (A) Score 0 (minimum), note that no edema is visible in the endometrial folds; (B) Score 1, note that a very small amount of edema is observed in the endometrial folds; (C) Score 2, note that a moderate amount of edema is present in the endometrial folds; and (D) Score 3 (maximum), note that a large amount of edema is present in the endometrial folds.

at $\mathrm{p}<.05$. The graphs were prepared using a commercial software (GraphPad Prism version 7).

\section{Results}

Summaries of uterine features (edema, tone, and echotextures) are depicted in Figs. 4 and 5. At the onset of treatment, uterine edema was not significantly different between G1 and G4, and between G2, G6, G7, and G8 (Fig. 4). Overall, animals in G7 had consistently lower edema scores than remaining groups $(\mathrm{p}<.05)$. Uterine tone and ultrasonography echotexture scores at the time of the embryo transfers were lower for all synchronized mares (G2-G8) in comparison to the scores recorded for mares in the control group (G1) ( $\mathrm{p}<0.05$ ) (Fig. 5). Interesting that 65\% (14/20) of mares in G5 (i.e., group with a pre-ovulatory $\geq 35 \mathrm{~mm}$ ) ovulated after commencement of the hormone treatments.

Overall, there was no effect of day for pregnancy rates for recipient mares having embryos transferred on Days $+3,+4,+5,+6$, +7 , and $+8(\mathrm{p}>.05)$. There were no differences in the pregnancy rates among hormonally synchronized groups in G2-G6 and G8 and G1 (control group) ( $<$.05) (Table 1). Whereas G7 (i.e., group with a fresh ovulation receiving a single injection of dinoprost on Day -4 ), had significantly lower conception rates compared to the remaining groups (Table 1).

\section{Discussion}

The present study aimed to optimize the synchronization of embryo recipient mares with donor mares. The hormone treatments described in this study were designed to mimic the natural ovarian steroid dynamic throughout the estrous cycle. Estrogen is produced in increasing amounts by the ovarian follicles at the beginning of estrus (i.e., Days -4 , to -2 before) and then it decreases the day before ovulation (Day -1) (Ginther, 1992). Therefore, mares received $10 \mathrm{mg}$ of estrogen on Days $-4,-2$, and -1 , but $20 \mathrm{mg}$ of 


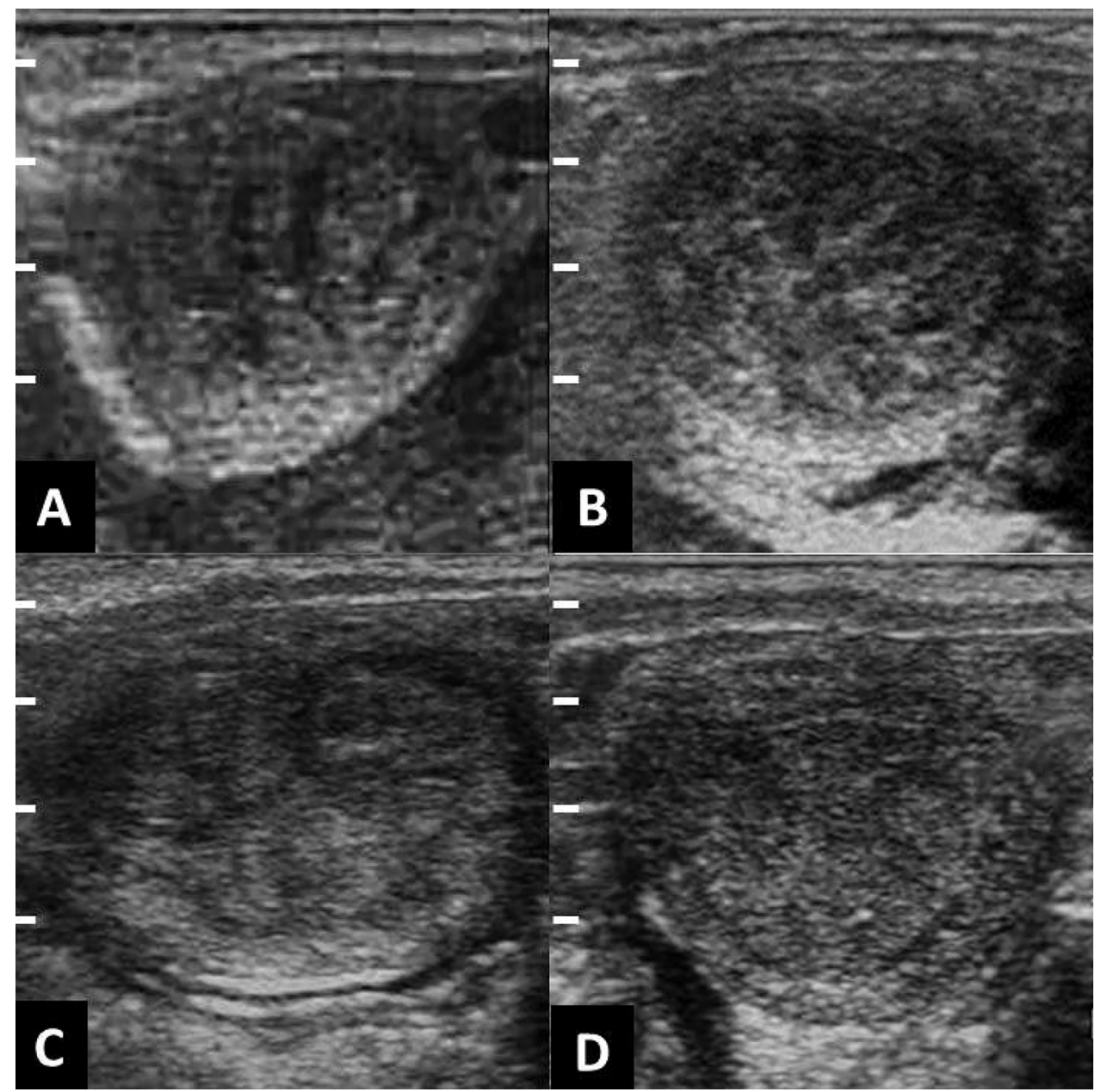

Fig. 3. Score system used to assess uterine echotexture immediately before embryo transfer. (A) Score 0 (minimum), note the heterogeneous uterine echotexture characterized by anechoic lines; (B) Score 1, note the less heterogeneous uterine echotexture characterized by less distinct anechoic lines; (C) Score 2 is similar to score 1 but with fewer anechoic lines; and (D) Score 3 (maximum), note a homogeneous uterine echotexture with no visible anechoic lines in the endometrial folds.

estrogen on Day -2 to mimic the estrogen dynamics during the estrous cycle. Additionally, the administration of a progestin (altrenogest) on Day 0 was aimed to mimic the day of ovulation, where there is an increase in peripheral progesterone concentrations following ovulation (Ginther, 1992). Also, this first dose of altrenogest was intended to prepare the uterus to receive the embryo (Days +3 to +8 ) and the second dose to maintain the pregnancy until the first diagnosis 5-7 days later. If pregnancy was confirmed in the first pregnancy diagnosis, long-acting progesterone was administered weekly until 120 day as previously reported (Vanderwall et al., 2007; Greco et al., 2010).

The embryo transfers carried out in the present study (Days +3 to +8 post altrenogest) were comparable with the synchrony between the ovulation of embryo donor and mares recipients of +3 to +8 . This asynchrony is consistent with satisfactory pregnancy rates reported by other authors (Wilsher et al., 2010; Jacob et al., 2012). In addition, if an embryo donor produces a negative embryo flushing, the same donor can have an embryo flushing repeated the next day or so, and in case an embryo is retrieved this embryo can still be transferred to the intended recipient, or an embryo from different a donor mare could be collected and transferred within the following 5 days.

Altrenogest has been demonstrated to maintain the pregnancy in acyclic and ovariectomized mares or mares suffering with luteal insufficiency (Hinrichs et al., 1986; Canisso et al., 2013a). Although this progestin is more expensive than long-acting progesterone, we elected to use altrenogest for the uterine preparation. Our clinical experience suggest that the long-acting altrenogest appears to be more consistently metabolized across animals in comparison with the long-acting progesterone used in the present study, thus in case that a recipient mare was not used for embryo transfer (i.e., negative embryo flushing) or had a negative pregnancy diagnosis, the mare could be reused for a new synchronization protocol. Long-acting progesterone appears to be slowly metabolized by some mares, thus making the mare unable to respond to estrogen treatment at the onset of a new synchronization protocol more consistently.

Pregnancy rates in the present study demonstrated that embryo recipient mares in various stages of estrous cycle, anestrus or spring transition can be synchronized with donor mares using a combination of prostaglandin, estrogen, and progestins. Our 

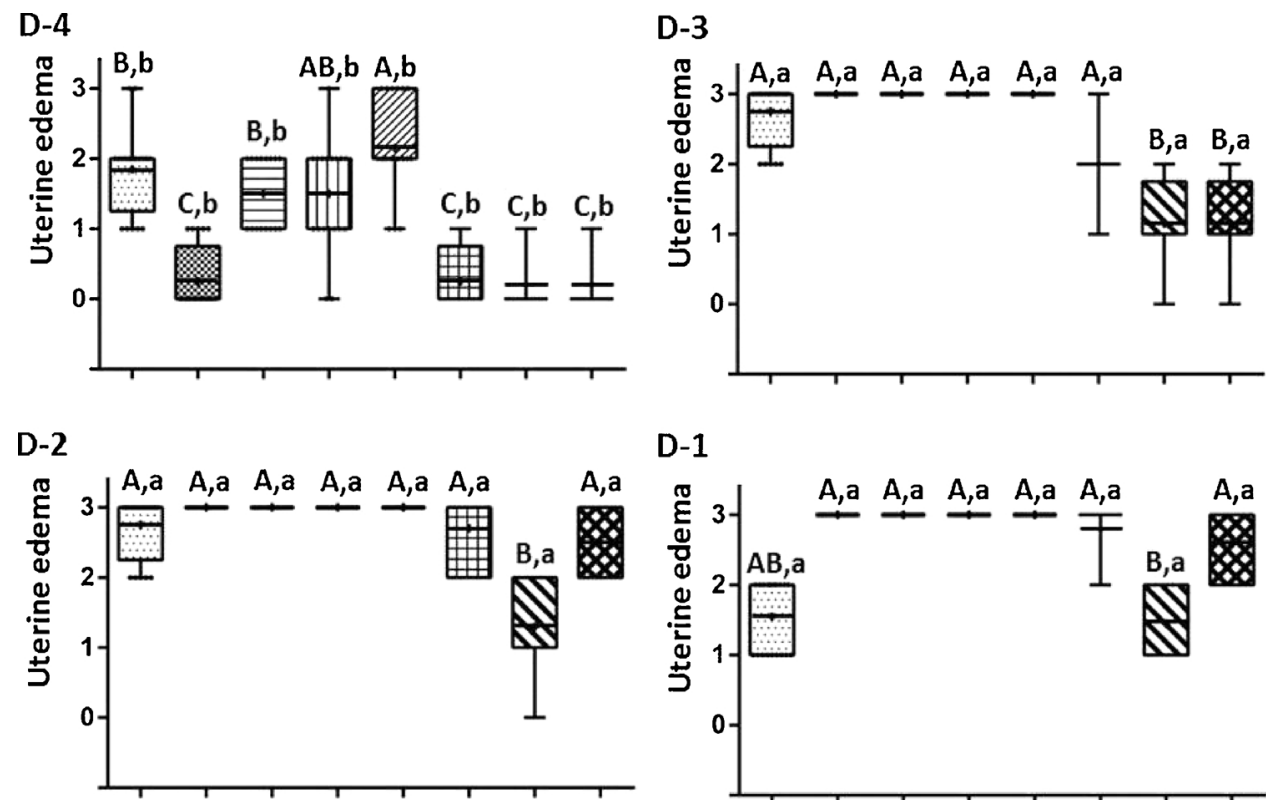

D-1

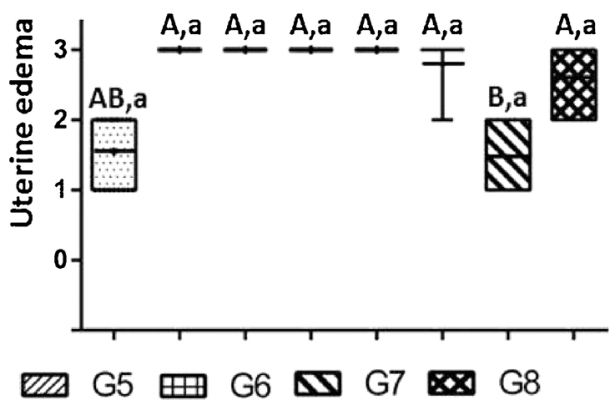

Fig. 4. Median and interquartile ranges of uterine edema scores during estrogen treatment (G2-G8) or the four days pre-ovulation (G1). (Upper left corner) Day -4; (Upper right corner) Day -3; (Lower left corner) Day - 2; and (Lower right corner) Day - 1. Uterine edema was scored via ultrasound (scale 0-3). Recipient mares ( $n=160$ ) were equally arranged into eight groups as follows: G1 spontaneous ovulation (control group); G2 anestrus; G3 spring transition; G4 early estrus (follicles $<35 \mathrm{~mm}$ ); G5 estrus (follicles $\geq 35 \mathrm{~mm}$ ); G6 diestrus (ovulation $\geq 5$ days); G7 early diestrus (ovulation $<5$ days) treated with a single dose of prostaglandin; and G8 early diestrus (ovulation $<5$ days) treated with two doses of prostaglandin. Different superscripts indicate statistical significance within groups across days (a,b,c) and within days across groups $\left({ }^{\mathrm{A}, \mathrm{B}, \mathrm{C}}\right)$.
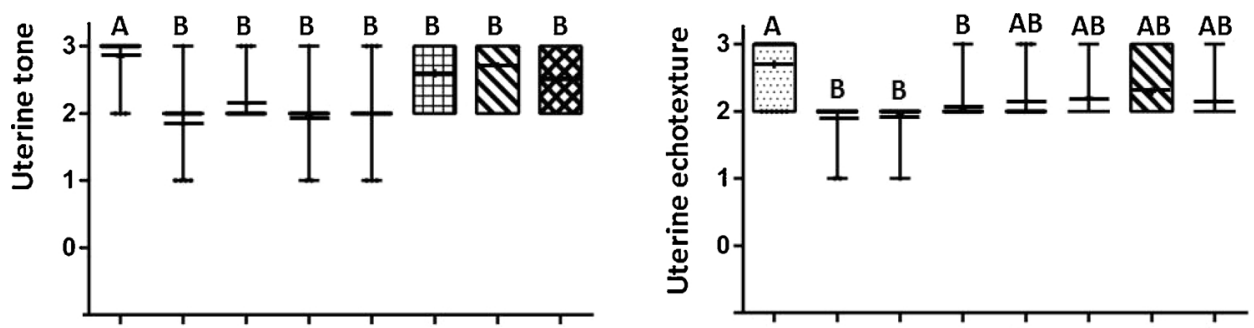

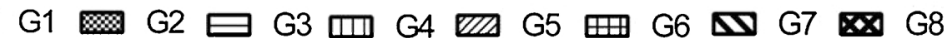

Fig. 5. Median and interquartile ranges of uterine tone (left) echotexture (right) scores assessed immediately before embryo transfer. Score 0 on represents a poor uterine tone and a heterogeneous echotexture, whereas, a score 3 represents a well-toned uterus with a homogenous echotexture. Recipient mares ( $\mathrm{n}=160$ ) were equally arranged into eight groups as follows: G1 spontaneous ovulation (control group); G2 anestrus; G3 spring transition; G4 early estrus (follicles < 35 mm); G5 estrus (follicles $\geq 35 \mathrm{~mm}$ ); G6 diestrus (ovulation $\geq 5$ days); G7 early diestrus (ovulation $<5$ days) treated with a single dose of prostaglandin; and G8 early diestrus (ovulation $<5$ days) treated with two doses of prostaglandin. Different superscripts $\left({ }^{\mathrm{a}, \mathrm{b}}\right.$ ) within variables (uterine tone, left; uterine echotexture, right) indicate statistical significance within days across groups.

pregnancy rates and losses were consistent with previous studies using progesterone treatment (Rocha Filho et al., 2004; Carnevale et al., 2005; Testa et al., 2005; Caiado et al., 2007; Kaercher et al., 2013; Greco et al., 2016) and cyclic recipients with no hormonal treatment (Carnevale et al., 2000; Greco et al., 2008). Though, mares with fresh ovulation ( $<5$ days) receiving one dose of prostaglandin (G7) had lower uterine edema scores during estrogen treatment and had remarkably lower conception rates compared with other groups. A recent study out of the Netherlands, demonstrated that pregnancy rate is positively correlated with the duration of uterine edema during estrous prior to the embryo transfer (Cuervo-Arango et al., 2017). Our findings in hormonally manipulated embryo recipient mares supports the claim by the Dutch group that showed that uterine edema is important for normal establishment of pregnancy in embryo recipient mares.

Previous studies demonstrated that administering a single dose of dinoprost (10 mg) during early diestrus does not result in proper luteolysis (as judged by the lack of reduction in peripheral progesterone concentrations), thus giving the false impression that mares do not respond to prostaglandin F2 $\alpha$ up to 5 days post ovulation (Coffman et al., 2014; Novaes Filho, 2014). Indeed, mares can respond to prostaglandin F2 $\alpha$ during the first 5 days post ovulation but require more than one dose (Novaes Filho, 2014). Absence of uterine edema in mares receiving prostaglandin $\mathrm{F} 2 \alpha$, a luteolytic agent, in association with estrogen, suggest that luteolysis was not 
Table 1

Pregnancy rates (pregnancies/embryos transferred) by 15, 30, 60 and 120 days of gestation.

\%Pregnancy rates (pregnancies/embryos transferred)

\begin{tabular}{llll}
\hline Groups & 15 days & 30 days & 120 days \\
\hline G1 & $75(15 / 20)^{\mathrm{A}}$ & $70(14 / 20)^{\mathrm{A}}$ & $70(14 / 20)^{\mathrm{A}}$ \\
G2 & $90(18 / 20)^{\mathrm{A}}$ & $90(18 / 20)^{\mathrm{A}}$ & $90(18 / 20)^{\mathrm{A}}$ \\
G3 & $90(18 / 20)^{\mathrm{A}}$ & $90(18 / 20)^{\mathrm{A}}$ & $90(18 / 20)^{\mathrm{A}}$ \\
G4 & $75(15 / 20)^{\mathrm{A}}$ & $70(14 / 20)^{\mathrm{A}}$ & $70(14 / 20)^{\mathrm{A}}$ \\
G5 & $70(15 / 20)^{\mathrm{A}}$ & $70(14 / 20)^{\mathrm{A}}$ & $70(14 / 20)^{\mathrm{A}}$ \\
G6 & $65(13 / 20)^{\mathrm{AB}}$ & $60(12 / 20)^{\mathrm{A}}$ & $60(12 / 20)^{\mathrm{A}}$ \\
G7 & $40(8 / 20)^{\mathrm{B}}$ & $30(6 / 20)^{\mathrm{B}}$ & $70(18 / 20)^{\mathrm{A}}$ \\
G8 & $75(15 / 20)^{\mathrm{A}}$ & $70(14 / 20)^{\mathrm{A}}$ & $70(14 / 20)^{\mathrm{A}}$ \\
\hline
\end{tabular}

G1 spontaneous ovulation (control group); G2 anestrus; G3 spring transition; G4 early estrus (follicles $<35 \mathrm{~mm}$ ); G5 estrus (follicles $\geq 35$ mm); G6 diestrus (ovulation $\geq 5$ days); G7 early diestrus (ovulation $<5$ days) treated with a single dose of prostaglandin; and G8 early diestrus (ovulation $<5$ days) treated with two doses of prostaglandin. Different superscripts $\left({ }^{\mathrm{AB}}\right.$ ) within the same column denote statistical differences.

complete, suggesting that there was some progesterone being produced by the freshly ovulated corpum luteum. A study showed that administration of progestins to mares with pre-ovulatory follicles had rapid inhibition of uterine edema and estrus (Canisso et al., 2013b). Thus, a second dose of prostaglandin F2 $\alpha$ given to mares in G8 likely ensured proper luteolysis and rescued pregnancy rates.

Of interest, in cows estradiol acts as a luteolytic agent, but not in mares (Souza et al., 2015). A recent study showed that embryo recipient mares treated with a single dose of estradiol $17 \beta(50 \mathrm{mg})$ at different stages of diestrus, followed by a dose of long-acting progesterone $(1500 \mathrm{mg})$, had lower uterine edema scores and pregnancy rates than acyclic mares treated with similar hormone treatments and cyclic mares receiving no hormones (Souza et al., 2015). This previous study also demonstrated that only mares showing uterine edema $\geq 2$ (similar to the grading used herein) became pregnant (Souza et al., 2015). Again, this finding is consistent with the Utrecht's study demonstrating that duration of uterine edema is important for normal pregnancy rates in embryo transfer recipient mares (Cuervo-Arango et al., 2017). In the present study, recipients mares with a fresh ovulation ( $<5$ days) had improved uterine features scores when a second dose of prostaglandin F2 $\alpha$ was given (G8). Collectively, it is suggestive that low peripheral progesterone is necessary for proper response to estrogen treatment and subsequent response to progestins and satisfactory pregnancy rates after embryo transfer.

Estrogen is responsible to activate progesterone receptors in the reproductive tract in preparation for pregnancy (Hughes and Evans, 1972; Allen, 2001). A minimal threshold of peripheral estrogen appears to be necessary for proper transcription of the gene codifying for the progesterone receptor. A recent study reported that administering $10 \mathrm{mg}$ of estradiol benzoate to acyclic mares resulted in greater uterine edema scores, and higher endometrial abundance of genes codifying for estrogen ( $\alpha$ and $\beta$ ) and progesterone receptors than mares treated with $5 \mathrm{mg}$ of estradiol benzoate (Fritsch, 2016). Of interest, there were no differences for mares treated with $10 \mathrm{mg}$ of estradiol benzoate and cyclic mares regarding the transcripts for progesterone and estrogen receptors (Fritsch, 2016).

Contrasting results were reported by a recent study by Silva et al. (2017). These authors suggested that administering $2.5 \mathrm{mg}$ of estradiol benzoate is the most suitable dose to emulate the physiological estrous cycle in acyclic recipient mares. The claim that a low dose of estradiol benzoate $(2.5 \mathrm{mg} / \mathrm{mare})$ is the more beneficial to acyclic mares than higher doses ( $5 \mathrm{mg}$ or $10 \mathrm{mg} / \mathrm{mare})$ is based on the finding that mares treated with low dose of estradiol benzoate had higher peripheral progesterone concentrations after receiving a single injection of $1500 \mathrm{mg}$ of long-acting progesterone. We speculate that higher doses of estradiol benzoate (e.g., 5 and $10 \mathrm{mg}$ ) as demonstrated by Fritsch (2016) resulted in higher expression of progesterone receptor in the reproductive tract than a low dose $(2.5 \mathrm{mg})$. Therefore, higher expression of the progesterone receptor in the reproductive tract, likely results in pronounced binding of progesterone to its receptor and consequent lower peripheral progesterone concentrations. Although this seems logical, such hypothesis has not been critically tested. Also, it is worth noting that while estradiol benzoate and estradiol $17 \beta$ may have similar potency and metabolism in horses, this remains to be determined.

Of practical interest, uterine tone and echotexture at the time of embryo transfer were lower in all hormone-treated mares than mares in the control group. Although this did not seem to affect the pregnancy rates, practitioners repeating this synchronization protocols should expect these differences when comparing with the same features with cyclic mares.

In present study, we recorded that $35 \%$ of mares in G5 (i.e., group with a preovulatory $\geq 35 \mathrm{~mm}$ ) did not ovulate after onset of estrogen treatments. This is consistent with a previous study demonstrating that estradiol treatment to mares with preovulatory follicles resulted in anovulatory follicles if estradiol therapy was initiated before LH surge (Greco, 2016). Similarly, mares exhibiting anovulatory follicles had increased estrogen concentrations four days before ovulation and administration of estradiol did not result in positive-feedback on peripheral LH concentrations (Ginther et al., 2006; Ginther et al., 2007). However, lack of ovulation in some mares in G5 did not affect pregnancy rates, since these mares had pregnancy maintained with progestins.

One of the perceived advantages of the described synchronization protocols is the potential reduction in the number of embryo recipient mares. Since embryo recipient mares at any stage of estrous cycle or anestrus or spring transition can be synchronized with the ovulation of donor mares, thus, this approach likely helps minimizing the costs of maintaining a large number of recipient mares. Another advantage is that ovulation failures can be circumvented. In practice, as much as $14.3 \%$ of the mares may fail to ovulate after hCG or GnRH analogs (Ginther et al., 2006; Yoon et al., 2007). 
The proposed hormone treatments may be very useful, but it requires administration of several hormone injections, needle-phobic embryo recipient mares may be difficult to handle. Additionally, according to the country or region some of the hormones may not be available or be legal for use in horses (e.g., estrogen is not allowed in countries where horses are slaughtered for human consumption), and the hormone-costs can be prohibitively expensive. In a typical clinical practice, embryo recipient mares are discharged from the embryo transfer facility to the care of the embryo's owner by 30-60 days after embryo transfer. Thus, pregnancy needs to be maintained with injection of long-acting progesterone 2-3 months after the mare is discharged to the care of embryo's onwer. However, some owners may not be dependable or willing to give weekly injection of hormones.

Anecdotally, it seems that some mares (not transferred, or not pregnant after embryo transfer) appear to have delayed ability to respond to a new synchronization protocol for as many as 30 days, based on the lack of uterine edema after estrogen administration to resynchronized mares. It is possible that long-acting altrenogest may last more than the currently labeled 7 days, but we are not certain.

Collectively, our results suggest that hormone treatment (prostaglandin, estradiol, and progestins) of mares in all stages of the estrous cycle (including freshly ovulated, i.e., < 5 days) or acyclic (anestrus or spring transition) can be useful to synchronize embryo recipient with donor mares. Overall, our pregnancy rates were consistent with previous studies and other successful commercial embryo transfer programs (except G7). Thus, we foresee that other groups may use the strategies described herein for the management of embryo recipient mares.

\section{Conflict of interest}

The authors CPFD, MAA, FOP, and JAD, are affiliated with Botupharma. The correspondent author owns the embryo recipient farm where the work was carried out.

\section{Acknowledgments}

The present manuscript represents the master's thesis of the first author. This study had no financial support. Botupharma Botucatu, São Paulo, kindly provided the hormones.

\section{References}

Allen, W.R., 2001. Luteal deficiency and mortality in the mare. Reprod. Domest. Anim. 36, 121-131.

Alvarenga, M.A., Landim-Alvarenga, F.C., Meira, C., 1993. Modifications in the technique used to recover equine embryos. Equine Vet. J. 25 (S15), 111-112.

Caiado, J.C., Fonseca, F.A., Siva, J.S., Fontes, R.S., 2007. Hormonal treatment of recipient mares of Mangalarga Marchador breed for embryo transfer on the secondday post ovulation. Bras. J. Anim. Sci. 36, 360-368.

Campbell, M.H., 2014. Embryo transfer in competition horses: managing mares and expectations. Equine Vet. Ed. 26 (6), $322-327$.

Canisso, I.F., Beltaire, K.A., Bedford-Guaus, S.J., 2013a. Premature luteal regression in a pregnant mare and subsequent pregnancy maintenance with the use of oral altrenogest. Equine Vet. J. 45 (1), 97-100.

Canisso, I.F., Gallacher, K., Gilbert, M.A., Korn, A., Schweizer, C.M., Bedford-Guaus, S.J., Gilbert, R.O., 2013b. Preovulatory progestagen treatment in mares fails to delay ovulation. Vet. J. 197 (2), 324-328.

Carnevale, E.M., Ramirez, R.J., Squires, E.L., Alvarenga, M.A., Vanderwall, D.K., McCue, P.M., 2000. Factors affecting pregnancy rates and early embryonic death after equine embryo transfer. Theriogenology 54, 965-979.

Carnevale, E.M., Coutinho da Silva, M.A., Panzani, D., Stokes, J.E., Squires, E.L., 2005. Factors affecting the success of oocyte transfer in a clinical program for subfertile mares. Theriogenology 64, 519-527.

Coffman, E.A., Pinto, C.F., Snyder, H.K., Leisinger, C.A., Cole, K., Whisnant, C.S., 2014. Antiluteogenic effects of serial prostaglandin f2(administration in mares. Theriogenology 82 (9), 1241-1245.

Cuervo-Arango, J., Claes, A.N., Ruijter-Villani, M., Stout, T.A., 2017. Likelihood of pregnancy after embryo transfer is reduced in recipient mares with a short preceding oestrus. Equine Vet. J. http://dx.doi.org/10.1111/evj12739.

Fleury, P.C., Alonso, M.A., Sousa, F.C., Andrade, A.C., Arruda, R.P., 2007. Uso da gonadotrofina coriônica humana (hCG) visando melhorar as características reprodutivas. Rev. Bras. Reprod. Anim. 31, 27-31.

Fritsch, S.C., 2016. Efeito da administração de diferentes doses de estradiol seguido de progesterona sobre a expressão de receptores endometriais de estrógeno e progesterona em éguas receptoras acíclicas. FMVZ Unesp, Botucatu (Masters thesis - In Portuguese).

Ginther, O.J., Utt, M.D., Bergfelt, D.R., Beg, M.A., 2006. Controlling interrelationships between progesterone/LH and estradiol/LH during the equine estrous cycle. Anim. Reprod. Sci. 95, 144-150.

Ginther, O.J., Utt, M.D., Beg, M.A., Gastal, E.L., Gastal, M.O., 2007. Negative effect of estradiol on luteinizing hormone throughout the ovulatory luteinizing hormone surge in mares. Biol. Reprod. 77, 543-550.

Ginther, O.J., 1992. Reproductive Biology of the Mare, Basic and Applied Aspects, 2th ed. Equine services Publishing, Cross Plains.

Greco, G.M., Avanzi, B.R., Fioratti, E.G., Queiroz, F.R., Meira, C., Alvarenga, M.A., 2008. Effect of interrupting progesterone administration to pregnant acyclic recipient mares showing the development of supplementary corpora lutea. In: Proceedings of 7th International Symposium on Equine Embryo Transfer 2008. July 9-11. Cambridge: Newmarket : R \& W Communications.

Greco, G.M., Dell'Aqua Jr., J.A., Alvarenga, M.A., 2010. Pregnancy and pregnancy loss rate of acyclic recipient mares treated with two different long-acting progesterone concentration. Reprod. Fertil. Dev. 22, 246.

Greco, G.M., Burlamaqui, F.G., Pinna, A.E., Queiroz, F.R., Cunha, M.S., Brandão, F.Z., 2012. Use of long-acting progesterone to acyclic embryo recipient mares. Rev. Bras. Zootec. Anim. 41 (3), 607-611.

Greco, G.M., Fioratti, E.G., Segabinazzi, L.G., Dell'Aqua Jr., J.A., Crespilho, A.M., Castro-Chaves, M.B., Alvarenga, M.A., 2016. Novel long-acting progesterone protocols used to successfully synchronize donor and recipient mares with satisfactory pregnancy and pregnancy loss rate. J. Equine Vet. Sci. 39 , 58-61.

Greco, G.M., 2016. Efficiency of Different Ovulation Inducing and Combinations on Uterine and Ovarian Characteristics and Plasmatic LH Concentrations in Mares. FMVZ Unesp, Botucatu (Doutorado Tese).

Hinrichs, K., Sertich, P.L., Kenney, R.M., 1986. Use of altrenogest to prepare ovariectomized mares as embryo transfer recipients. Theriogenology 26 (4), 455-460.

Hughes, J.P., Evans, J.W., 1972. Clinical and endocrine aspects of the estrous cycle of the mare. In: Proceedings of the 18th Annual Conference of the American Association of Equine Practitioners. San Francisco. pp. 119-152.

Jacob, J.C.F., Haag, K.T., Santos, G.O., Oliveira, J.P., Gastal, M.O., Gastal, E.L., 2012. Effect of embryo age and recipient asynchrony on pregnancy rates in a 
commercial equine embryo transfer program. Theriogenology 77, 1159-1166.

Kaercher, F., Kozicki, L.E., Camargo, C.E., Weiss, R.R., Santos, I.W., Muradas, P.R., Abreu, R.A., 2013. Embryo transfer in anovulatory recipient mares treated with estradiol benzoate and long-action progesterone. J. Equine Vet. Sci. 33, 205-209.

McCue, P.M., Squires, E.L., 2015. Equine Embryo Transfer, 1st ed. CRC Press.

McCue, P.M., Farquhar, V.J., Carnevale, E.M., Squires, E.L., 2002. Removal of deslorelin (Ovuplant) implant $48 \mathrm{~h}$ after administration results in normal interovulatory intervals in mares. Theriogenology 58, 865-870.

McKinnon, A.O., Squires, E.L., Voss, J.L., Cook, V.M., 1988. Equine embryo transfer: a review. Compend. Contin. Educ. Vet. 10, $343-355$.

Novaes Filho, L.F., 2014. Resposta Luteal à PGF2alfa (Dinoprost trometamina) durante as fases de luteogênense e manutenção do corpo luteos em éguas (Master thesis - In Portuguese). FMVZ Unesp, Botucatu.

Panzani, D., Rota, A., Pacini, M., Vannozi, I., Camillo, F., 2007. One-year-old fillies can be successfully used as embryo donors. Theriogenology 67 (2), 367-371.

Pinto, M.R., Miragaya, M.H., Burns, P., Douglas, R., Neild, D.M., 2017. Strategies for increasing Reproductive efficiency in a commercial embryo transfer program with high performance donor mares under training. J. Equine Vet. Sci. 54, 93-97.

Rocha Filho, A.N., Pessoa, M.A., Gioso, M.M., Alvarenga, M.A., 2004. Transfer of equine embryos into anovulatory recipients supplemented with short or long-acting progesterone. Anim. Reprod. Sci. 1, 91-95.

Silva, E.M., Ignácio, F.S., Fritsch, S.C., Zanoni, D.S., Pantoja, J.F., Oliveira-Filho, J.P., Meira, C., 2017. Administration of 2.5 mg of estradiol followed by 1, 500 mg of progesterone to anovulatory mares promote similar uterine morphology, hormone concentrations and molecular dynamics to those observed in cyclic mares. Theriogenology 97, 159-169.

Souza, R.R., Fontes, J.G., Zorzetto, M.F., Silva Junior, A.B., Papa, F.O., Alvarenga, M.A., 2015. Sincronização de receptoras no diestro para utilização em programa de Transferência de Embriões em equinos. Vet. Zootec 22 (2), 245-253.

Squires, E.L., McCue, P.M., Vanderwall, D., 1999. The current status of equine embryo transfer. Theriogenology 51, 91-104.

Testa, A.C., Carmo, M.T., Alvarenga, M.A., 2005. Perda embrionária precoce em éguas receptoras de embrião em anestro tratadas com progesterona de longa ação. Acta Sci. Vet. 33, 198-200.

Vanderwall, D.K., Marquardt, J.L., Woods, G.L., 2007. Use of a compounded long-acting progesterone formulation for equine pregnancy maintenance. J. Equine Vet. Sci. 27 (2), 62-66.

Wilsher, S., Clutton-Brock, A., Allen, W.R., 2010. Successful transfer of day 10 horse embryos: influence of donor-recipient asynchrony on embryo development. Reproduction 139, 575-585.

Yoon, M.J., Boime, I., Colgin, M., Niswender, K.D., King, S.S., Alvarenga, M.A., Roser, J.F., 2007. The efficacy of a single chain recombinant equine luteinizing hormone (reLH) in mares: induction of ovulation, hormone profiles, and inter-ovulatory intervals. Domest. Anim. Endocrinol. 33 (4), $470-479$. 